\title{
Introduction of Agricultural Insurance Services in Benin: Lessons from a Preliminary Evaluation of Service Used by Farmers in Tori-Bossito (Southern Benin)
}

\author{
Océane A. Y. A. Legba ${ }^{1}$, Augustin K. N. Aoudji ${ }^{1,2, *}$, Gautier S. B. Bohissou ${ }^{1}$, Jean C. Ganglo ${ }^{2}$ \\ ${ }^{1}$ School of Economics, Socio-Anthropology and Communication for Rural Development, \\ Faculty of Agricultural Sciences, University of Abomey-Calavi, Benin \\ ${ }^{2}$ Laboratory of Forest Sciences, School of Environmental Management, Faculty of Agricultural Sciences, \\ University of Abomey-Calavi, Benin
}

Copyright $(2017$ by authors, all rights reserved. Authors agree that this article remains permanently open access under the terms of the Creative Commons Attribution License 4.0 International License

\begin{abstract}
Price and production risks are among the critical challenges faced by smallholder farmers in Sub-Saharan Africa. Agricultural insurance is viewed as a good option to manage these risks, and is being promoted across Sub-Saharan African countries. Therefore, this study was conducted in Benin to evaluate how the agricultural insurance service meets the needs and expectations of smallholder farmers, in a context widespread production loss. A survey was carried out between June and July 2015 in Tori-Bossito district (southern Benin) where 120 farmers were selected based on stratified sampling. Structured interviews were conducted to collect data on farmers' socio demographic characteristics, their production system, their knowledge on the 'Assurance Mutuelle Agricole du Bénin (AMAB)' the agricultural insurance company - and the use of its services. $90.8 \%$ of farmers reported production losses every year. The level of losses reached half of the expected production for $75 \%$ of respondents. However, the agricultural insurance company (AMAB) was unknown to $43.3 \%$ of farmers; and only $1 \%$ of them subscribed to an insurance policy. The offer of agricultural insurance did not meet farmers' expectation. As lesson learnt from this study, AMAB needs to upgrade its communication strategy, and service package, to meet farmers' expectations. Decision makers should also work for a combination of agricultural insurance with other drivers of rural development, e.g., the access to credit, to production inputs, and to market.
\end{abstract}

Keywords Agricultural Insurance, Price Risk, Production Risk, AMAB, Tori-Bossito, Benin

\section{Introduction}

Food security and poverty remain major policy concerns in developing countries, especially in the rural areas of Sub-Saharan Africa $[1,2]$. It is argued that the ability of the region to address these challenges will depend on productivity and growth in the agricultural sector $[3,4,5]$. The critical place of agriculture in Sub-Saharan Africa's economy stems from its general role of food provider, and its importance in the livelihood of the population. It accounts for about $15 \%$ of total GDP in Sub-Saharan Africa, and employs more than $50 \%$ of the total work force [6]. Even though agribusiness and commercial agriculture are being promoted across Sub-Saharan Africa in recent years [7, 8], smallholder farmers still represent the overwhelming majority of farms in the region, and employ almost all the agricultural workforce [9].

Smallholder farmers in Sub-Saharan Africa face various challenges such as limited inputs and credit, inadequate infrastructure, etc. $[10,11]$, resulting in constrained productivity growth. Price and production risks are other challenges the management of which is receiving increased attention [12, 13], as they result in income drop and instability over time $[12,14]$. The protection of smallholder farmers against these shocks is expected to reduce risk aversion, enhance investment, and achieve a sustained increase in production. This will help to build resilience among smallholder farmers and ultimately, contribute to poverty alleviation [12].

In Sub-Saharan Africa, production loss is mainly due to climate change and variability [15]. To cope with the climatic risks, two main strategies are generally proposed [16]. The first one consists of preventing the climatic risk based on agricultural techniques such as irrigation, the optimization of the farming calendars, the use of suitable varieties, etc. The second strategy is based on a posteriori compensation for the income loss through agricultural insurance $[12,17]$.

The agricultural insurance is a financial protection for the farmers against the loss of their harvests $[17,18]$. This 
risk management mechanism is being developed in various regions in Sub-Saharan Africa. In Benin, the agricultural insurance was unveiled through the AMAB in 2007. While agricultural insurance is advocated as a good option to manage price and production risk [12, 18, 19], it is also crucial to evaluate its acceptability to farmers. Therefore, the following question is of importance to decision makers. How well do the proposed agricultural insurance services meet the needs and expectations of smallholder farmers? The objective of this study was to evaluate the agricultural insurance in Benin, so as to support the development of services meeting smallholder farmers' needs. Although this study took place in southern Benin, it is useful to enlighten decision makers across Sub-Saharan Africa, given the importance of price and production risks across the region, and the need to develop reliable instruments to manage these shocks.

This manuscript progresses as follows. The research methods are developed in the next section. Results appear in section 3, and discussion of the results is presented in section 4. In the last section, the main findings are summarized with the related policy implications.

\section{Methods}

\subsection{Study Area}

The study was carried out in Tori-Bossito district, in the Atlantique department, southern Benin (Figure 1). This district was selected because it hosts the regional office of $\mathrm{AMAB}$ in the Atlantique department, hence a relative proximity of the insurance service to the farmers of this district. This is important to understand farmers' relation to the agricultural insurance services. Therefore the presence of an operational office of AMAB in Tori-Bossito enables to address, to some extent, the constraint of the physical access of farmers to the services, and to better understand the fundamental reasons their of adhesion or not to agricultural insurance.

In Tori-Bossito the climate is subequatorial, with two rainy seasons alternating with two dry seasons. The annual rainfall averaged $1100 \mathrm{~mm}$ [20]. The average monthly temperatures ranged between 27 and $31^{\circ} \mathrm{C}$ across the year
[21]. The topography of Tori-Bossito consists mainly of a low plateau. Four types of soil are found across the district: ferralitic soils in the North; hydromorphic soils in the East and the extreme West; black cotton soils in the South, and tropical ferruginous soils in the West [20].

The hydrographical network of the district is composed of marshes, backwaters and small rivers. The population of Tori-Bossito is 57,632 people [22]. The main activities are crop production, animal production, trade, crafts, fishing and agri-processing [23].

\subsection{Data Collection}

Data collection started with a meeting with $A M A B$ representatives in Tori-Bossito. This enabled to collect data on the insurance services offered and the various rules of subscription, and determination of premium and compensation amounts. Then a survey was carried out among farmers in Tori-Bossito district, using a stratified sampling. The stratification was based on the criterion of the dominant crops across the district (Table 1). The target population was the farmers holding at least 0.25 ha of utilized agricultural land. This criterion was based on the availability of agricultural land in the district [24]. The urban sub-districts of Tori-Bossito and Tori-Gare were excluded from the study since the focus was on agricultural production. One to three villages were randomly selected per sub-district based on their demographic weigh. This procedure enabled to enroll a total of 120 farmers in the survey.

Data collection took place between June and July 2015, and consisted of face-to-face interviews based on a standardised questionnaire. The main points dealt with during the interviews were as follows: farmer's identification and geographical location, socio-demographic data, characteristics of the production system, the existence and extent of crop losses, and the knowledge of AMAB (the Insurance Company) and the use of its services. Besides, the road distance from AMAB regional office in Tori-Bossito to each village (Table 1) was measured with a Global Positioning System. This distance ranges between $4.2 \mathrm{~km}$ and $20 \mathrm{~km}$, and averaged $11.19 \mathrm{~km}$. 


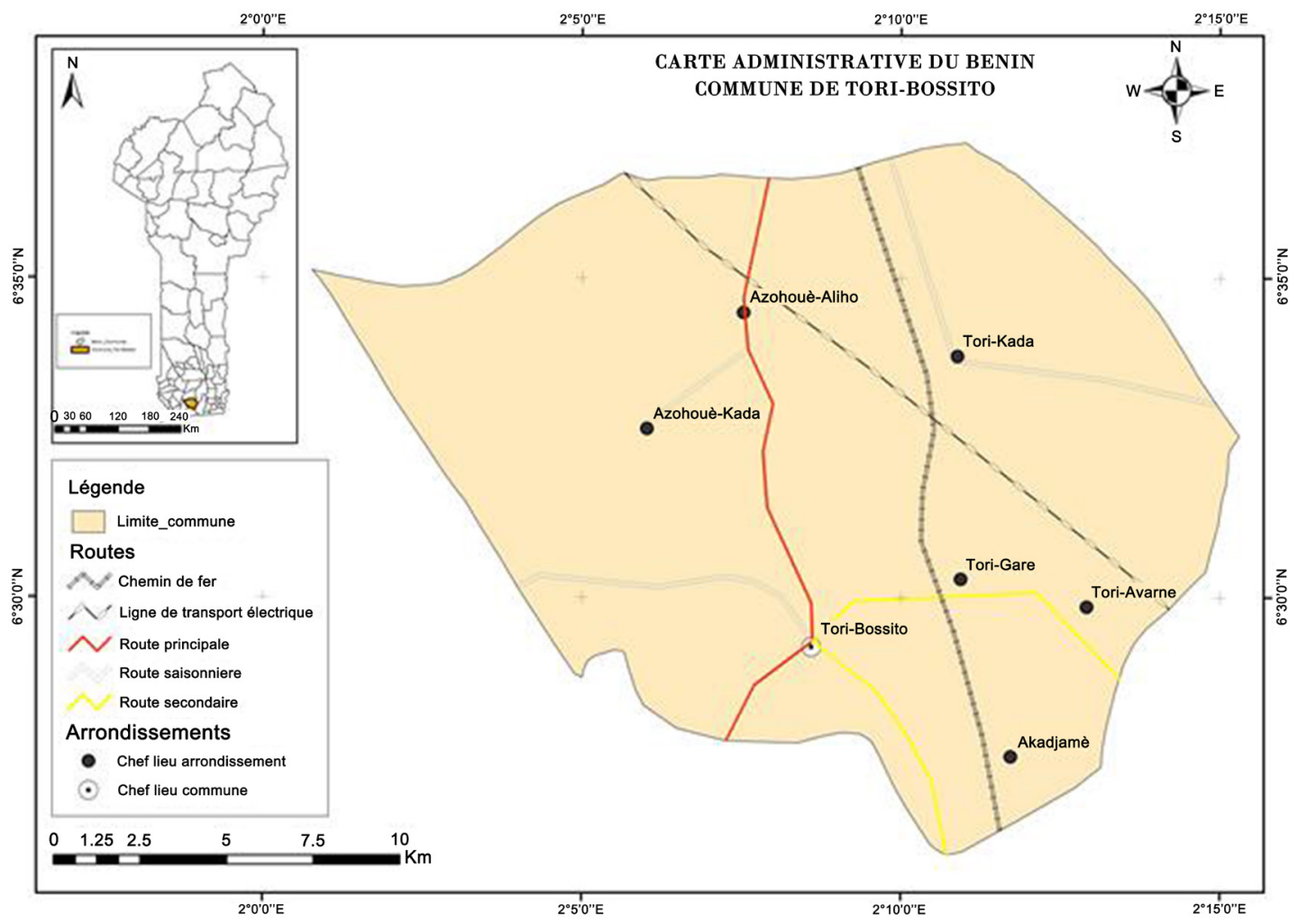

Figure 1. Map of Tori-Bossito district

Table 1. Main crops and distance from selected villages to AMAB's regional office in Tori-Bossito

\begin{tabular}{|c|c|c|c|}
\hline \multirow{2}{*}{ Crop } & Sub-districts & Villages & $\begin{array}{c}\text { Road } \\
\text { distance to } \\
\text { AMAB office }\end{array}$ \\
\hline \multirow{2}{*}{ Pineapple } & Tori-Cada & Lokossa & $9.6 \mathrm{~km}$ \\
\cline { 3 - 4 } Tomatoes & \multirow{2}{*}{ Azohouè-Cada } & Zoungoudo & $8 \mathrm{~km}$ \\
\cline { 3 - 4 } & & Satré & $20 \mathrm{~km}$ \\
\cline { 3 - 4 } & Azongo & $18 \mathrm{~km}$ \\
\hline \multirow{2}{*}{$\begin{array}{c}\text { Vegetables } \\
\text { crops }\end{array}$} & Tori-Avamè & Zounvessehou & $13 \mathrm{~km}$ \\
\hline \multirow{2}{*}{$\begin{array}{c}\text { Maize/ } \\
\text { cassava }\end{array}$} & Azohouè-Aliho & Houngo & $6.7 \mathrm{~km}$ \\
\cline { 3 - 4 } & Hayakpa & $4.2 \mathrm{~km}$ \\
\hline
\end{tabular}

\subsection{Data processing and Analysis}

Data processing and result compilation included the following stages: (i) overview of agricultural insurance service in Benin, (ii) socio-demographic characteristics of the sample, (iii) farmers' production systems, (iv) access to finance and technical support, (v) description of production losses, and (vi) farmers' knowledge and use of agricultural insurance services.

The overview of agricultural insurance services consisted of the presentation of each type of insurance, the validity period of the policy, the amounts of premium and compensation for various risks. Data processing for the socio-demographic characteristics of farmers, their production systems, and the access to finance and technical support was done through the calculation of descriptive statistics on relevant variables (percentages, means and standard deviation). Regarding the description of production losses, it was dealt with the percentage of farmers affected periodically, the agricultural production concerned and the magnitude of losses. In the last point, the percentage of farmers who knew the existence of AMAB and its service was calculated as well as the percentages of the various channels of knowledge. The relation between the geographical location and farmers' knowledge of AMAB services was analyzed based on the Pearson's Chi-Square test of Independence [25].

\section{Results}

\subsection{Agricultural Insurance Service in Benin}

The Mutual Agricultural Insurance of Benin (AMAB) was launched on December 18th, 2007 by the farmers. This is a mutual organization with about 1,000 members at its inception. It offers classical insurances services (car, individual accident, hospitalization), as well as agricultural insurances services (Multi-Risk Harvests, livestock mortality, conservation and storage of agricultural products) that are presented hereafter.

The "Multi-Risk Harvests" insurance is a scheme of financial compensation, in case of crop losses due to 
disasters such as: bush fires on crops or tree plantations, crop damage by wild animals (except livestock in transhumance); crop or plantations damage by grasshopper invasion; and losses in quantity of harvest due to excessive rainfall. Eligible crops to this insurance include: maize, cashew nut, cotton, cassava, groundnut, bean, yam, oil palm plantation, millet, sorghum, citrus fruits, mango trees, onions, potatoes, pepper, rice, and tomato. The insurance certificate is valid from the issuing date, and expires twelve (12) months later or after product harvest. The allowance is calculated by multiplying the quantity of deficit by the agreed unit price (e.g., per kg). The average yields of crops in the departments serve in allowances calculation. In practice the value of output is considered. For instance, if the value of the expected output for 1 ha is XOF 150,000 (average exchange rate during the survey period: USD $1=$ XOF 596.56), the annual premium is XOF 12,000 . For an output of XOF 100,000, the annual premium is XOF 8,000. The ceiling of compensation also matters in premium determination for agricultural risks (Table 2). Allowance should be paid within 30 days after a disaster.

Table 2. Examples of premium for different agricultural risks

\begin{tabular}{|c|c|c|}
\hline $\begin{array}{c}\text { Type of losses or } \\
\text { damages }\end{array}$ & $\begin{array}{c}\text { Annual Premium } \\
\text { (XOF) }\end{array}$ & $\begin{array}{c}\text { Ceiling of } \\
\text { compensation (XOF) }\end{array}$ \\
\hline Crop losses due to rain & 10,000 & 100,000 \\
\hline Crop losses due to fire & 5,000 & 100,000 \\
\hline $\begin{array}{c}\text { Damages caused by wild } \\
\text { animals }\end{array}$ & 6,000 & 50,000 \\
\hline
\end{tabular}

The Insurance for livestock Mortality" is a warranty against the loss incurred by livestock owners. This insurance can be subscribed for horses (1 to 14 years age), male cattle (6 months to 6 years), dairy cow (6 months to 8 years), sheep (6 months to 5 years), goats (6 months to 5 years) and swine (6 months to 5 years). The insurance applies in case of accidental death, official killing for sanitary reasons, drowning, evisceration, bush fires and poisoning. The insurance contract is valid for one year. It is renewed each year until the animals reach the upper age limits, unless there is cancellation by any of the parties. The subscription fees are calculated based on the commercial value of the animals which is the ceiling allowance in case of disaster. For example, the annual premium is XOF 30,000 for an animal of XOF 500,000 value; for those with a commercial value of XOF 100,000, the annual premium is XOF 10,000 .

The "Conservation and Storage" insurance covers fire hazards and explosions of agricultural produce stored in warehouses. This insurance applies for the produce as well as for the buildings and other goods inside. The target of this insurance service includes agro- industries, farmers, and other stakeholders. The annual premium for damages to stored food products is XOF 7,500 with a compensation ceiling of XOF 50,000.

\subsection{Socio-demographic Characteristics of the Farmers}

The sample was dominated by men representing about 9/10. Farmers' age ranged between 21 and 90 years, and averaged 42 (Table 3 ). About $3 / 5$ of them did not attend formal education. About one quarter attended primary school; one tenth attended secondary school; and a small proportion had a university degree (Table 3 ). Household size varied between 1 and 26 people, and averaged 8 members. Regarding the availability of family labour, it ranged between 1 and 11 workers per household and averaged 2 . Farming was overwhelmingly the main activity of households across the sample.

Table 3. Socio-demographic characteristics of farmers

\begin{tabular}{|c|c|c|}
\hline Variables & Categories & Value \\
\hline \multirow{2}{*}{$\operatorname{Sex}(\%)$} & Male & 87.5 \\
\hline & Female & 12.5 \\
\hline \multirow{4}{*}{ Age (years) } & Minimum & 21 \\
\hline & Maximum & 90 \\
\hline & Average & 42 \\
\hline & Standard deviation & 14 \\
\hline \multirow{3}{*}{ Marital status (\%) } & Married & 90.2 \\
\hline & Single & 9.0 \\
\hline & Widowed & 0.8 \\
\hline \multirow{4}{*}{$\begin{array}{l}\text { Size of the } \\
\text { household }\end{array}$} & Minimum & 1 \\
\hline & Maximum & 26 \\
\hline & Average & 8 \\
\hline & Standard Deviation & 5 \\
\hline \multirow{4}{*}{$\begin{array}{l}\text { Instruction level of } \\
\text { the household head } \\
\text { (\%) }\end{array}$} & No schooling & 56.7 \\
\hline & Primary school & 23.3 \\
\hline & Secondary school & 14.2 \\
\hline & University & 5.8 \\
\hline \multirow{5}{*}{ Main activity (\%) } & Farming & 88 \\
\hline & Trade & 2 \\
\hline & Crafts and transport & 1 \\
\hline & Motorcycle taxi & 3 \\
\hline & $\begin{array}{c}\text { Other (Officials, local elected } \\
\text { officials, and Professional) }\end{array}$ & 7 \\
\hline \multirow{4}{*}{$\begin{array}{l}\text { Number of family } \\
\text { workers }\end{array}$} & Minimum & 1 \\
\hline & Maximum & 11 \\
\hline & Mean & 2 \\
\hline & Standard deviation & 2 \\
\hline
\end{tabular}

\subsection{Farm Size and Activities}

The farm size ranged across the sample between 0.25 and 14 ha, and averaged 2 ha. Maize was the most grown crop (39.2\% of respondents). Farmers also grew cassava, tomato, and pineapple (up to $50 \%$ of the surveyed households for the three crops). Lastly, approximately $5 \%$ 
of the farmers were involved in animal production (goats, sheep and poultries), oil palm cropping, bean cropping, and small-scale forestry (figure 2).

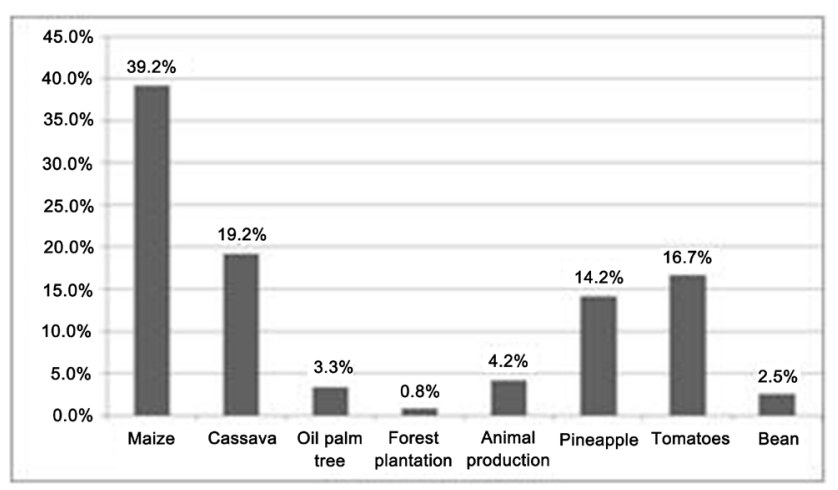

Figure 2. Agricultural productions carried out by Farmers

\subsection{Access to Finance and Technical Supports}

Only $11.7 \%$ of respondents in the sample claimed access to credit in the formal system. The amount of loans ranged between XOF 30,000 and XOF 1,250,000 with a standard deviation of XOF 328,921 . The institutions granting loans included microfinance institutions (50\% of respondents), NGO (21.4\%), banks (7.1\%) and groups/associations (21.4\%).

Very few farmers were members of professional organizations. Examples of organizations included farmers unions, groups of mutual aid and cooperatives. Technical supports Organizations (NGO, public extension service) were working with $46.7 \%$ of farmers surveyed.

\subsection{Production Losses}

$90.8 \%$ of the farmers reported the occurrence of production loss each year. The products concerned were maize $(35 \%)$, pineapple $(3.3 \%)$, tomato $(2.5 \%)$, animal production $(2.5 \%)$, gardening $(1.7 \%)$, cassava $(0.8 \%)$ and groundnut $(0.8 \%)$. Drought was the main cause of these losses $(50 \%)$. Other factors included flood $(0.8 \%)$, pests $(1.7 \%)$, damages by animals $(0.8 \%)$, and the lack of outlets because of price volatility in agricultural markets (6.7\%). In $75 \%$ of cases, half of the production was lost (Figure 3 ). The losses of $10-50 \%$ of the production were reported in $22.5 \%$ of cases (Figure 3 ).

\subsection{Farmers' Knowledge and Use of Agricultural Insurance Services}

The study revealed that AMAB was unknown to $56.7 \%$ of respondents. Among those knowing AMAB's services $(43.3 \%)$ of the sample had been informed through the radio, the main source of information (40.4\%). The other channels of knowledge were as follows: the sensitizing by AMAB staff (17.3\%), the view of the company office in Tori-Bossito (15.4\%). Others were informed through parents $(7.7 \%)$, friends $(5.5 \%)$, professional groups and associations $(7.7 \%)$, chiefs of village $(3.8 \%)$ and the staff of national agricultural extension service (1.9\%).

Pearson's Chi-Square test of independence showed a relation between the farmers' knowledge of AMAB's services and their geographical location $(\mathrm{p}<0.05)$. Therefore, the farmers of Houngo would be better informed about AMAB and its services, than those of Satré (Table 1).

Some farmers adhered to AMAB which consists of paying XOF 5,000 to have the status of member of the mutual insurance company. The subscription to the insurance policies involves the payment for a financial protection in case of disasters. $5 \%$ of the farmers interviewed were members of $\mathrm{AMAB}$ while only $1 \%$ subscribed to an agricultural assurance. The reasons supporting the adhesion to AMAB were: to address crop losses $(16.7 \%)$, the perception of AMAB's services as useful $(16.7 \%)$ and loan seeking (16.7\%). Regarding the subscription, two services were concerned: the "Multi-Risk Harvests" insurance and the "Individual accidents" insurance. The majority of farmers $(95 \%)$ had neither adhered to AMAB, nor subscribed to one of its service. The main reasons are the ignorance of the existence of the insurance company, and the distrust against financial institutions. There was also the perception that the subscription premium was too high, and the services distant and unreliable/unfair.

However, $78.3 \%$ of respondents recognized the subscription to agricultural insurance as a good option to cope with crop losses, and have access to the financing of commercial banks. Therefore, farmers pledged for some changes such as lower premium (10.8\%), faster payment of the compensation (13.3\%) and the inclusion of loan $(51.7 \%)$.

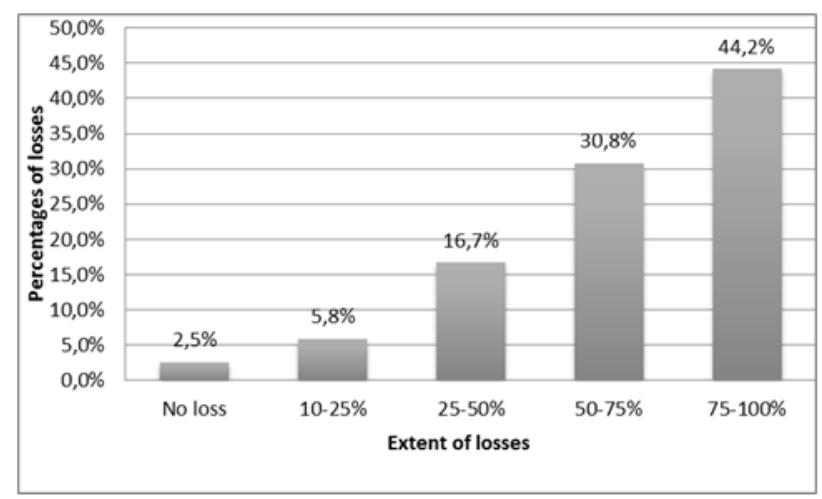

Figure 3. Level of Production Losses

\section{Discussion}

\subsection{Activities and Agricultural Production System}

Agriculture was the main activity in the study region (88\% 
of households) but auxiliary occupations were found (petty trade, craft, transportation, etc.). Women represented a small proportion of the sample, and often face difficulties in land access. Therefore they were more active in agri-products processing, compared to agricultural production. The land cultivated by women often belongs to their husband, other family members; but in rare cases, the land is purchased [26].

Besides the diversity of activities, farmers' production systems are characterized by a diversity of crops thus highlighting strategies of livelihoods diversification. This strategy of diversification has proven effective to improve livelihood security and to raise living standards of rural household $[27,28]$. This diversification is also helpful to farmers to address the climatic risk and the potential losses on some crops [29].

Though the farming systems are characterized by a diversity of crops, maize was produced by all farmers across the study area. The popularity of maize in the production system is not a single pattern of Tori-Bossito district; because it is the main crop at nation level [30], with a critical importance in the diet of most people [31].

\subsection{Production Losses}

The study revealed that almost all farmers $(97.5 \%)$ were facing production losses each year. In $75 \%$ of cases the losses incurred exceeded half of the production. This represents an alarming threat because the losses affect mainly maize, a major food crop for the population [31]. This could be an impediment to food security and livelihood of people given the socio-economic importance of maize and the magnitude of losses (up to $100 \%$ of maize production in some cases). Production loss was reported in other regions of Sub-Saharan Africa [32, 33, 34], hence the utility of an insurance service.

By order of decreasing importance, the main drivers of the production losses were drought, price instability on agricultural products markets, pests and animals, and the flood. In about $2 / 5$ of cases, the losses affected several crops at the same time. Drought was reported as a major cause of yield loss in other regions in Sub-Saharan Africa $[35,36,37]$. The rain-fed agricultural system of production practiced in the study area is often undermined by climatic variability which increases the risk on the production, given the prevalence of the drought among the causes of the production losses (periodical drought episodes affecting crop productivity). Besides, farmers faced loss for pineapple, because poor roads conditions hampered the quick transfer of the fruits to the local markets, resulting in losses. Also, the lack of customer and the drop of the price at certain periods cause losses on mature pineapple crops. The poor road infrastructure is known as an impediment to market access for smallholder farmers in Sub-Saharan Africa; and addressing this constraint is advocated as a critical policy matter to tackle poverty and food insecurity in the region $[38,39,40]$. Though affordable insurance services are useful, this study confirms the existence of other avenues to address smallholder farmers' difficulties, e.g. improved rural infrastructure and market access $[40$, 41].

\subsection{Knowledge of AMAB and the Use of its Services}

Among the services offered by AMAB, the "Multi-Risks Harvest" insurance is likely the most suited to farmers, given the predominance of crop production in the farming system. The "Multi-Risks Harvest" insurance is a type of indicial insurance based on regional yields [42].

The study revealed that AMAB was unknown to the majority of farmers. For those who knew its existence, the radio was the main channel of knowledge $(2 / 5$ of respondents), while the sensitization done by AMAB's staff reached less than one fifth of farmers. These results confirm that the radio is a reliable channel to disseminate information in rural regions [43]. Also from this result, the effectiveness of the company's communication is questionable, hence the need of revisiting it.

There was a small proportion of adhesion and subscription to agricultural insurance services by farmers. Four potential reasons supporting this are explained hereafter. First, the limited number of subscribers might stem from the ignorance of the services and their usefulness by most farmers. Second, farmers' reluctance is also due to unfortunate experiences in recent past with institutions of micro-finance which failed to deliver reliable services. Third the result might also highlight the weak attractiveness of the insurance service to farmers. In fact most farmers who adhered to AMAB complained about the cost of the insurance services which is viewed as relatively expensive. Also for those farmers, the index insurance based on regional yields is viewed as disadvantageous, given that the yields at department level might not reflect the losses incurred by the subscribers. The fourth reason is the existence of endogenous systems of risks management. These mechanisms include the membership of mutual assistance group and the help from relatives (parents, friends) in period of difficulties [44], but their effectiveness is questionable.

The results showed a wrong perception of AMAB's services by farmers. In fact, the majority of farmers are mistaken about the nature of the mutual insurance company and the services it has been offering. Therefore AMAB was considered as a classical institution of micro finance, so that farmers' interest vanishes when they finally realize that it is not the case. In the literature, it was reported that farmers could subscribe more readily to agricultural insurance if this is associated with a credit [14]. I was also argued that if the insurance is associated with a loan managed by the same organization, the costs would be reduced [45]. For example, in May 2011, Cameroonian farmers pledged for the combination of insurance service 
with the financing and not in isolation [44]. That way, it might be possible to farmers to pay the insurance premium, and invest in the means of production, for improved productivity [44].

The increased use of agricultural insurance service by farmers would require a viable business strategy from $\mathrm{AMAB}$, to make the service attractive to farmers. This involved a review of the communication strategy, as well as the responsiveness in paying farmers in case of disaster. It is also critical to work in a long term vision to have an increased number of subscribers. Last, the cooperation with institutions of microfinance will be an effective mean to increase farmers' access to credit while motivating them to take advantage of the agricultural insurance services.

\section{Conclusions}

The focal target of this study was to generate the diagnosis of the agricultural insurance service in Benin, and its use by the farmers in the district of Tori-Bossito. The results showed that $90.8 \%$ of farmers face production losses every year. The importance of these losses reaches $50 \%$ of the production in $75 \%$ of cases. This high level of production losses is mainly due to drought, as a consequence of the predominant rainfed farming system, and price instability on agricultural products markets. Despite this high level of losses, only $1 \%$ of farmers subscribed to the agricultural insurance which could help to manage price and production risks. This weak interest of the farmers in agricultural insurance services is supported by the following reasons: (i) the ignorance by farmers of the existence of agricultural insurance services, (ii) the wrong understanding of the services offered by AMAB, (iii) the relatively high service cost as perceived by the farmers, and (iv) the existence of endogenous systems of risks management (mutual aid and traditional saving groups).

As lesson from this study, the insurance company needs to upgrade its communication strategy, and the quality of services proposed to farmers, so as to meet their expectations. That communication might include the clarification of the mechanisms of calculation of premium and amount of compensation, to show the transparency of the service. The strengthening of staff's capabilities might be useful for timely assessment of disasters and compensation payment. Finally, decision makers should work for a combination of agricultural insurance with other drivers of rural development, especially the access to credit, to production inputs, and to market.

\section{REFERENCES}

[1] D.P. Garrity, F.K. Akinnifesi, O.C. Ajayi, S.G. Weldesemayat, J.G. Mowo, A. Kalinganire, M. Larwanou, J.
Bayala. Evergreen Agriculture: a robust approach to sustainable food security in Africa. Food Security, 2 (3):197-214, 2010.

[2] H.C.J. Godfray, J.R. Beddington, I.R. Crute, L. Haddad, D. Lawrence, J.F. Muir C. Toulmin. Food Security: The Challenge of Feeding 9 Billion People. Science, 327(5967):812-818, 2010.

[3] J. Kydd, A. Dorward, J. Morrison, G. Cadisch. Agricultural development and pro - poor economic growth in Sub Saharan Africa: potential and policy. Oxford Development Studies, 32 (1): 37-57, 2004.

[4] J.M Staatz, N.N Dembélé. Agriculture for Development in Sub-Saharan Africa. Washington, DC, World Bank, 2008.

[5] FAO Regional overview of food insecurity: African food security prospects brighter than ever. Accra, FAO, (2015). Online available: http://www.fao.org/3/a-i4635e.pdf (31/08/2017).

[6] IMF (International Monetary Fund). International Jobs Report, Economist Intelligence Unit, Washington, DC, 2012.

[7] K. E. Banson, N. C. Nguyen, O. J. H. Bosch, T. V. Nguyen. A Systems Thinking Approach to Address the Complexity of Agribusiness for Sustainable Development in Africa: A Case Study in Ghana. Syst. Res, 32: 672-688, 2015.

[8] A. A. Adenle, L. Manning, H. Azadi. Agribusiness innovation: A pathway to sustainable economic growth in Africa. Trends in Food Science \& Technology, 59:88-104, 2017.

[9] D. Gollin. Smallholder agriculture in Africa: An overview and implications for policy, IIED. IIED, London, 2014.

[10] J. Swinnen, L. Colen, M. Maertens. Constraints to smallholder participation in high-value agriculture in West Africa, In: Rebuilding West Africa's Food Potential, A. Elbehri (ed.), FAO/IFAD, 2013.

[11] C. McIntosh, A. Sarris, F. Papadopoulos. Productivity, credit, risk, and the demand for weather index insurance in smallholder agriculture in Ethiopia. Agricultural Economics, 44 (4-5): 399-417, 2010.

[12] L. Antonaci, M. Demeke, A. Vezzani. The challenges of managing agricultural price and production risks in sub-Saharan Africa. Rome, FAO, 2014.

[13] C.A. Harvey, Z.L Rakotobe, N.S. Rao, R. Dave, H. Razafimahatratra, R.H. Rabarijohn, H. Rajaofara, J.L. MacKinnon. Extreme vulnerability of smallholder farmers to agricultural risks and climate change in Madagascar. Philosophical Transactions of the Royal Society B: Biological Sciences 369 (1639), 2014.

[14] P. Hazell, J. Anderson, N. Balzer, A. Hastrup Clemmensen, U. Hess, F. Rispoli. L'assurance basée sur un indice climatique: potentiel d'expansion et de durabilité pour l'agriculture et les moyens de subsistance en milieu rural, Programme alimentaire mondial PAM/FIDA. Roma, Italia, 2010.

[15] A. Salami, A.B. Kamara, Z. Brixiova. Smallholder Agriculture in East Africa: Trends, Constraints and Opportunities, African Development Bank, Tunis, Tunisia, 2010. 
[16] D. Lagandré, A. Chetaille. L'assurance indicielle, une réponse face aux risques climatiques? Grain de sel, 49, 20-21, 2010.

[17] B. Sarr, S. Atta, L. Kafando. Revue des indices climatiques utilisés dans les systèmes d'assurances agricoles indicielles en Afrique. Secheresse, 23 : 255-260, 2012.

[18] M.A. Tadesse, B.A. Shiferaw, O. Erenstein. Weather index insurance for managing drought risk in smallholder agriculture: lessons and policy implications for sub-Saharan Africa. Agricultural and Food Economics, 3: 26, 2015.

[19] F.N. Nnadi, J. Chikaire, J. A. Echetama, R. A. Ihenacho, P. C. Umunnakwe, C. O. Utazi. Agricultural insurance: A strategic tool for climate change adaptation in the agricultural sector. Net Journal of Agricultural Science, 1 (1):1-9, 2013.

[20] S. Akoha. Evaluation des recettes générées par les plantations privées de teck (Tectona grandis L.f.) : cas des plantations de la commune de Tori-Bossito (Sud-Bénin). Parakou, Bénin. 2009.

[21] A.I. Quenum. Etude dendrométrique et contribution à la gestion des plantations de Tectona grandis L.f au Sud-Bénin : cas de la commune de Tori-Bossito. Benin, 2002.

[22] INSAE. Résultats provisoires du Recensement Général de la Population par Habitant (RGPH4). Cotonou, 2013.

[23] L.S. Ahlonsou, M.D. Houndonougbo. Plan de Développement Communal de Tori-Bossito (2005-2009). Mairie de Tori-Bossito, 2005.

[24] A.O.Y.A. Legba. Diagnostic de l'utilisation des services d'assurance agricole par les agriculteurs de la commune de Tori-Bossito (Sud-bénin). Abomey-Calavi, Benin, 2015.

[25] F. Mazerolle. Glossaire de statistiques descriptives, 2010. Online Available: http:

//www.info.univ-angers.fr/-gh/wstat/perfectionnement $\mathrm{r} / \mathrm{m}$ azerolle-khi-carre.pdf.

[26] R.L. Mongbo. Disponibilité en terres et régime foncier en milieu rural au sud Bénin, in: P. Lavigne Delville, C. Toulmin, S. Traoré, (Eds.), Gérer le foncier rural en Afrique de l'Ouest - Dynamiques locales et interventions publiques. Karthala-URED-Ministère des Affaires Étrangères, Paris, Saint-Louis, 2000.

[27] F. Ellis. Household strategies and rural livelihood diversification. The Journal of Development Studies, 35 (1): 1-38, 1998.

[28] S.A. Loison. Rural Livelihood Diversification in Sub-Saharan Africa: A Literature Review. The Journal of Development Studies, 51(9): 1125-1138, 2015.

[29] P.J.M. Cooper, J. Dimes, K.P.C Rao. B. Shapiro, B Shiferaw, S. Twomlow. Coping better with current climatic variability in the rain-fed farming systems of sub-Saharan Africa: An essential first step in adapting to future climate change? Agriculture, Ecosystems \& Environment, 126 (1-2): 24-35, 2008 .

[30] MAEP. Plan Stratégique de Relance du Secteur Agricole PSRSA. Bénin, 2011.
[31] C. Mitchikpè, E.A.D. Atègbo, A.J. Fanou, C.M. Nago. Consommation alimentaire des ménages urbains au Bénin. CERN, CIRAD, Montpelier, 2001.

[32] J.M. Olwoch, B. Reyers, F.A. Engelbrecht, B.F.N. Erasmus. Climate change and the tick-borne disease, Theileriosis (East Coast fever) in sub-Saharan Africa. Journal of Arid Environments, 72 (2): 108-120, 2008.

[33] W. Schlenker, D.B. Lobell. Robust negative impacts of climate change on African agriculture. Environmental Research Letters 5 (1): 1-8, 2010.

[34] E. Blanc. The Impact of Climate Change on Crop Yields in Sub-Saharan Africa. American Journal of Climate Change, 1(1):1-13, 2012

[35] P. Webb, T. Reardon. Drought Impact and Household Response in East and West Africa. Quarterly Journal of International Agriculture, 31 (3): 230-247, 1992.

[36] R.M. Leichenko, K.L. O'Brien. The Dynamics of Rural Vulnerability to Global Change: The Case of southern Africa. Mitigation and Adaptation Strategies for Global Change, 7 (1):1-18, 2002.

[37] P.J.A. van Asten, A.M. Fermont, G. Taulya. Drought is a major yield loss factor for rainfed East African highland banana. Agricultural Water Management, 98 (4): 541-552, 2011.

[38] G.F Ortmann, R.P. King. Agricultural cooperatives II: Can they facilitate access of small-scale farmers in South Africa to input and product markets? Agrekon, 46 (2) : 219-244, 2007.

[39] E. Ouma, J. Jagwe, G.A. Obare, S. Abele. Determinants of smallholder farmers' participation in banana markets in Central Africa: the role of transaction costs. Agricultural Economics, 41 (2): 111-122, 2010.

[40] A.K.N. Aoudji, A. Adégbidi, V. Agbo, G. Atindogbé, S.S.M. Toyi, A.S.I. Yêvidé, J.C. Ganglo, P. Lebailly. Functioning of farm-grown timber value chains: lessons from the smallholder-produced teak (Tectona grandis L.f.) poles value chain in Southern Benin. Forest Policy and Economics, 15:98-109, 2012.

[41] X. Diao, D. Headey, M. Johnson. Toward a green revolution in Africa: what would it achieve, and what would it require? Agricultural Policy, 39 (1): 539-550, 2008.

[42] R. Iturrioz, (Ed). Assurance Agricole. World Bank, Washington. 2012.

[43] R. Chapman, R. Blench, G. Kranjac-Berisavljevic, and A.B.T. Zakariah. Rural radio in agricultural extension: the exemple of vernacular radio programmes on soiland water conservation in N. Ghana, Agricultural Research and Extension Network paper, 2003.

[44] CIMA. Etude sur la micro assurance dans la zone CIMA-Etats des lieux et recommandations. Dossier 2011.

[45] B. Muller. Index based crop insurance in Senegal and West Africa: some concerns based on on-going experiments, 2012. 